\title{
La Gigantomaquia, símbolo socio-político en la concepción de la polis griega *
}

\author{
Cristina Delgado Linacero **
}

\begin{abstract}
RESUMEN
ABSTRACT

Este estudio

This survey proposes a Gigantomachy propone una interpretación del mito de myth interpretation as a political and la Gigantomaquia como simbolo político y sociológico de la evolución de la ciudad griega. Está basado en fuentes literarias y visuales que aparecieron entre los siglos VIII y II a.C. El desafio final a la autoridad de los Olímpicos viene de los Gigantes, hijos de Gaia, nacidos de las gotas de sangre brotada de los miembros emasculados de Urano. Fue el tema del friso norte del Tesoro de los Sifnios en Delfi y tuvo una importancia particular en las metopas orientales del Partenón (Acrópolis de Atenas) y sobre el gran friso del altar de Pérgamo. El análisis trata de aportar alguna luz sobre el modo en que los griegos entendieron su propia historia. sociological symbol in the Greek polis evolution. It is based on literary sources and visual arts created between VIIIth and IIth centuries B.C. The final challenge to the authority of the Olympians came from the Giants, sons of Gaia born from the drops of blood that fell from Ouranos' severed members. It was the subject on the north frieze of the Siphinian Treasury at Delphi and had a particular importance on the eastern metopes of the Parthenon (Acropolis of Athens) and on the altar large frieze at Pergamon. The analysis intends to throw some light on the Greek way to understand their own history.
\end{abstract}

* Este trabajo se ha beneficiado parcialmente de una subvención de la DGICYT (PBOISG/94).

** Doctora en Historia del Arte. Laboratorio de Arqueozoología (UAM). 


\section{INTRODUCCIÓN}

Desde los tiempos más remotos de la Historia, todas las grandes civilizaciones han tratado de dar una respuesta religiosa a las más profundas e inquietantes preguntas del hombre. Así se han ido tejiendo hermosos mitos, leyendas y complicadas doctrinas filosóficas, cuyas huellas se advierten en todas las manifestaciones del desarrollo humano. El mundo griego ha legado a la civilización occidental un rico patrimonio cultural en el que los mitos no podían faltar. Tras ellos se ocultan noticias históricas y códigos de conducta, cuyo conocimiento contribuye a aclarar nuestros propios orígenes. Uno de los mitos primigenios y doctrinales de la narrativa helénica fue el de la Gigantomaquia, lucha cosmogónica entre dioses y gigantes desarrollada en el inicio de los tiempos. Su argumento intentaba resolver, de modo admirable, algunos de los insondables misterios a que se enfrentó el mundo antiguo: la Creación y la existencia del Mal sobre la tierra. Su temporal secuencia evolutiva implicó, a la vez, una serie de nociones y conceptos, que integraron la realidad psicológica y social, ética, ideológica e institucional del helenismo. La reiterada elección de este episodio, como vehículo de expresión y propaganda al servicio del estado, convirtió su exégesis en algo siempre novedoso y pragmático. Desde sus arcaicos orígenes hasta bien entrado el período helenístico, el mito multiplicó su presencia en la literatura y en el arte, interpretándose una y otra vez bajo el prisma del momento en que existió.

La versión más completa del mito se debe a Apolodoro, (Bibl. I. 6,1 ss.). Según este autor tardío, los gigantes eran vástagos de Gea (la Tierra) y de la sangre derramada por Urano (el Cielo) tras ser emasculado por su hijo Cronos. El motivo de su nacimiento fue vengar a sus hermanos, los Titanes, condenados por Zeus a los profundos abismos del Tártaro. Viendo amenazaba su soberanía, el padre de los dioses buscó el apoyo de las divinidades olímpicas. Su interés se centró, en especial, en Atenea y en el héroe Heracles, cuya ascendencia semihumana era condición indispensable para, según un oráculo, vencer en la empresa. Gea, entonces, se esforzó en encontrar la planta de la inmortalidad, que crecía en su suelo, para salvar a su prole, pero Zeus impidió brillar a los dioses de la luz (Eos, Helios y Selene), sumiendo a la tierra en total oscuridad hasta apropiarse del hallazgo. El enfrentamiento de los beligerantes finalizó con la derrota de los gigantes.

Los más antiguos testimonios literarios sobre el tema se remontan a Homero y Hesíodo, (s. VIII-VII a.C.). Es probable que Apolodoro tuviese ya noticias de estas y otras versiones posteriores, tal vez retazos o referen- 
cias, y a través de su recopilación, hiciese una reconstrucción del mito. Ninguno de los dos autores arcaicos mencionan la celebración de la contienda, pero sí la aparición de los gigantes. Homero (Od. VII. 56-60; 205206) explica su pertenencia a una raza salvaje, acaudillada por el rey Eurimedonte, quien les llevó a la perdición por causas que el poeta no reseña. Hesíodo, (Teog. 183 ss.) refiere su origen semidivino y su llegada al mundo como adultos de gran tamaño, ataviados con brillantes armaduras y empuñando largas lanzas. Este aspecto formal de los gigantes, un tanto ennoblecidos por el uso de las armas, revela el influjo de la epopeya homérica, (II. XIII. 169 ss.), cuyos protagonistas guerreaban como hoplitas. Por otro lado, el poeta, (II. XVI. 143). les une con lazos fraternales a las Erinias y a las Ninfas Melíades, moradoras de los bosques de fresnos. De este modo, propicia su misión vengativa y les brinda la posesión de lanzas, cuya madera de fresno las transforma en mortíferos proyectiles para aniquilar héroes. La sola presencia de estos seres sugiere ya el desencadenamiento del conflicto y la perversidad que llevan consigo.

Sería Píndaro, (Nem. I. 67), el primero en mencionar la crucial ofensiva, situando el campo de batalla en la llanura de Flegra, en la península de Palene, dentro de la región de Arcadia. Es precisamente en época de este gran poeta beocio, (s. VI a.C.), cuando se documentan los primeros testimonios artísticos con esta tesis. Probablemente, la forma literaria del mito debió estar ya consiituida en torno al s. VIII a.C. O, al menos, no más tarde del S. VI a.C. Su fuente de inspiración podría no ser totalmente griega, sino derivar de patrones mucho más antiguos procedentes del mundo oriental. Ecos de ello se hallan en la leyenda de origen anatolio, del combate entre el dios de la tempestad hitita y el dragón Illuyanka. Aquí, el primero llama en su ayuda a otras divinidades y también al héroe Hupashiya, hijo suyo y de una mortal ${ }^{1}$; el Enuma Elish, obra del genio mesopotámico, relata también el triunfo de la alianza divina dirigida por Marduk contra Tiamat (el Caos) y sus terribles criaturas ${ }^{2}$. Igualmente, existen otros precedentes de seres concebidos tras la emasculación paterna. Así, Kumarbi, padre de los dioses en la mitología hurrita-hitita, genera tres hijos tras haber mordido en los muslos a su progenitor $\mathrm{Anu}^{3}$. Por otro lado, gigantes terribles, como el acadio Humbaba, vencido por Gilgamesh, tampoco fueron desconocidos ${ }^{4}$.

LARA, F. (1987). Textos literarios hititas. Madrid, págs. 33 ss.

LARA, F. (1994). Enuma Elish. Madrid.

LARA, F. (1987). Opus cit. pág. 147.

LARA, F. (1987). Opus cit. págs. 109 ss. 
Las representaciones figurativas de aquellos pueblos plasmaron estos y otros mitos religiosos en escenas de carácter belicoso, donde a menudo el monarca reemplazaba al protagonista divino, asumiendo el heroico papel del vencedor. Personajes asiendo por el cabello al humillado oponente, asestándole un golpe mortal o luchando sobre su cuerpo yacente son frecuentes en los repertorios de la imaginería egipcia, mesopotámica o del levante asiático (fig. 1). Su influencia es patente en el arte griego hasta el final del período helenístico. Los modelos se repiten una y otra vez, con simples variaciones estéticas.

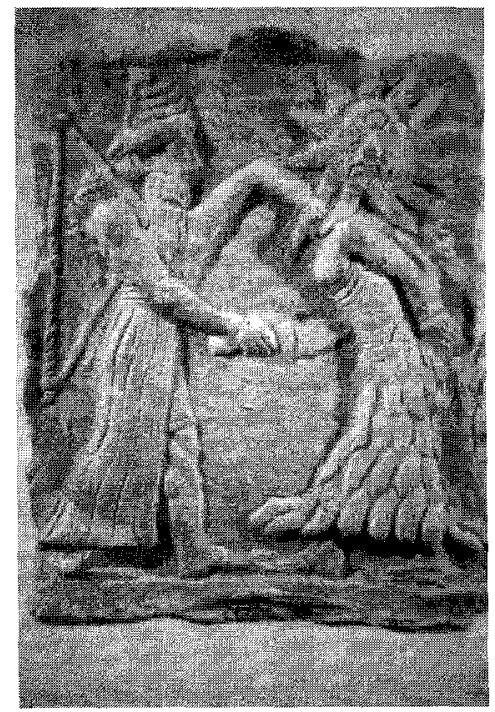

Fig. 1. Placa. Tell-Khafajeh (Mesopotamia). 2000-1600 a.C. Terracota. M. Bagdad.

\section{EL ARCAISMO}

En el $\mathrm{s}$. VI a.C., las representaciones más antiguas aparecen simultáneamente en la cerámica ática y corintia. Las imágenes de los gigantes se concretan en dos patrones principales, de acuerdo con los perfiles establecidos por Homero y Hesíodo. Uno de ellos va armado al modo hoplítico, completando a menudo su atuendo con vestido corto, manto o cota de cuero sobre la coraza. Las piernas se protegen con grebas. Es el más extendido. Otro, en cambio, va desnudo como signo de primitivismo y brutalidad, al que se añade una barba tupida, unos grandes mostachos y unas gruesas trenzas que asoman bajo el casco corintio. A veces esgrimen piedras como 


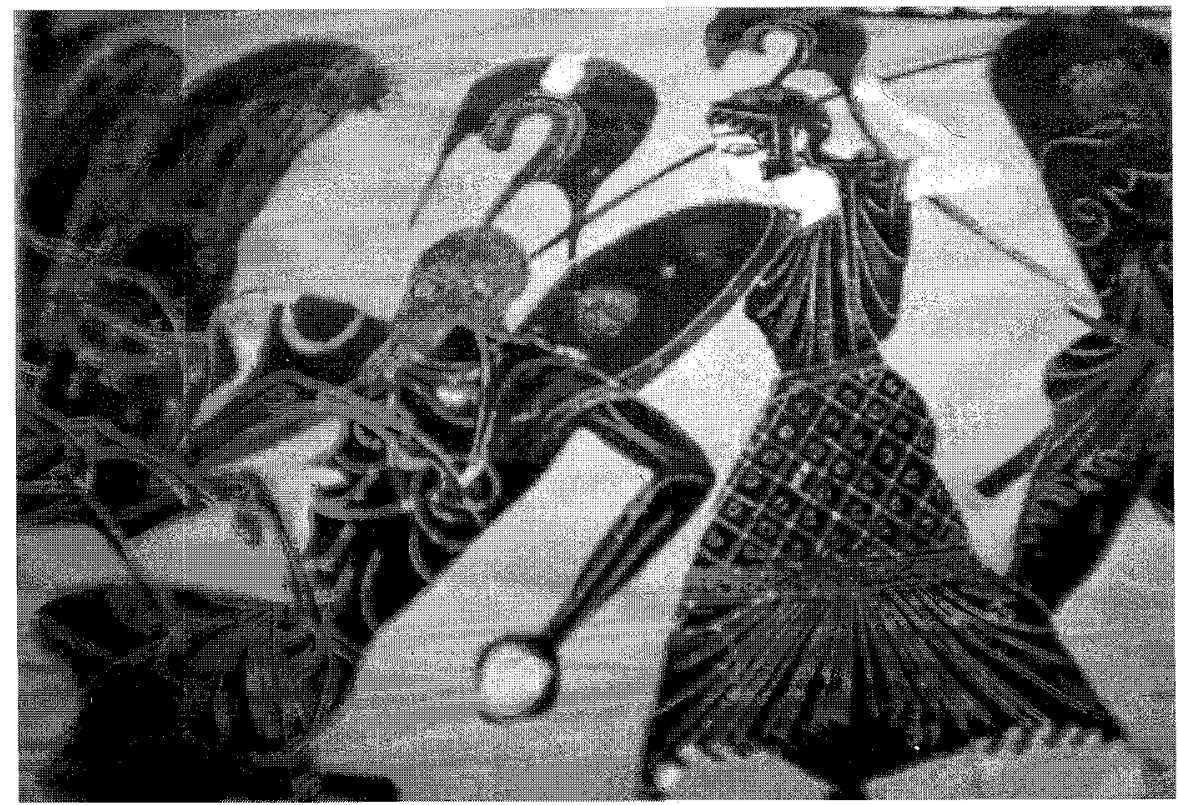

Fig. 2. Psikter. Grecia. 530-520 a.C. M. Rice (Houston, Texas).

armas arrojadizas (fig. 2). Su único auxilio es Gea, su madre, que emerge de la tierra, alzando los brazos en ademán de clemencia.

Es en estos inicios iconográficos, cuando el mito parece haber adoptado su intrínseco carácter como encarnación de ciertos valores esenciales del pensamiento y de la sociedad griega. En efecto, el s. vl a.C. fue un momento de consolidación política y cultural de la polis. El ejercicio de gobierno mediante fórmulas de dominio totalitarias dejó paso a la implantación de un orden abstracto, donde el reparto de poder fuera más igualitario. Este ideal político de isonomía fue surgiendo a través de la renovación moral, que tuvo lugar entre el s. vII y el $v$ a.C. Resultado de ello fue la condenación de todo exceso y violencia, así como la exaltación de la medida, la moderación y el autocontrol. Planteamientos de este tipo se muestran ya en Solón, arconte de Atenas en 594 a.C., quién impulsó la ley y la justicia como principales instrumentos para limitar la desmesura y como elementos indispensables para el desarrollo de la ciudad, (Eleg. mus. Frs. 1, 5). Más adelante, Heráclito de Efeso, que vivió entre el 535 y el 470 a.C., percibirá la ley y la justicia como el cumplimiento de un orden divino, concebido como un logos o razón del que participaban todos los hombres, (Frs. B. 41; B. 2; B. 114). Por su parte, Jenófanes de Colofón, 
coetáneo del anterior y precursor de la Escuela de Elea, afirmaba que los hombres debían orar a los dioses para poder actuar con justicia, (Frs. 1, 13 ss.). Así pues, la victoria de Zeus y sus huestes celestes debía interpretarse como la instauración de una nueva organización del universo, como el advenimiento de lo que podría denominarse la polis divina. El despecho y la furia de los gigantes debían ser aplastados por la equidad del logos pensante. La ley divina debía imponerse como garantía de la estabilidad del cosmos entero y de los seres que lo habitaban. Las fuerzas del mal tenían que ser derrotadas por los incorruptibles poderes del Bien.

Atenea y Heracles prestaron su valiosa ayuda en defensa de la soberanía de su padre. La primera compartió con él la metis de su progenitora, astucia o inteligencia práctica que la dotaba de su sagacidad para vencer en la guerra y de su magisterio en el adiestramiento técnico, en la paz. Ambas virtudes la hicieron digna de ejercer junto a Zeus el patronazgo de la ciudad de Atenas, erigida como polis modélica hasta el final del mundo antiguo. La imperativa intervención de Heracles, estableció una alianza entre el hombre y la divinidad, quebrando a la vez, la barrera infranqueable entre ambas esferas. El héroe se constituyó, así, en símbolo de la liberación individual y, a través de sus hazañas, en el guerrero indomable que triunfó siempre del salvajismo de hombres y bestias. Su purificador holocausto y su elevación a las regiones olímpicas le convirtieron, además, en receptor privilegiado de aquella mágica planta de la inmortalidad, denegada a los hijos de la Tierra, (Sof. Traq. 1160 ss.). W. Burket ${ }^{5}$ y F. Polignac ${ }^{6}$ asocian la función del culto al héroe con la evolución, que tuvo lugar en la polis a partir del 750 a.C. Ven en ello una expresión de solidaridad ciudadana. No cabe duda del enorme prestigio alcanzado por Heracles en Grecia, hasta el punto de que Píndaro le atribuye la fundación de los Juegos Olímpicos, el acontecimiento panhelénico por excelencia, (Olim. X, 55-60).

Nada tiene de extraño que, de acuerdo con lo dicho, sean Zeus, Heracles y Atenea el grupo elegido por ceramistas y escultores para muchas de las escenas de la Gigantomaquia. Ellos fueron los actores principales de la lucha contra los gigantes y los verdaderos artífices de la victoria final. El padre de los dioses suele estar subido en una cuadriga de caballos al galope, acompañado por Heracles, que hace las veces de au-

Burket, W. (1985). Greek Religion. Cambridge, pág. 204.

Polignac, F. (1984). La naissance de la cité grecque. Cultes, espace et societé VIII-VII siecles avant J.C. Paris, págs. 128-131. PLÁCIDO, D. (1997). La imagen heroica de la Atenas democrática. En D. Placido, J. Alvar, J. Casilllas, C. Fornis. Imágenes de la polis. Madrid, págs. 127-134. 


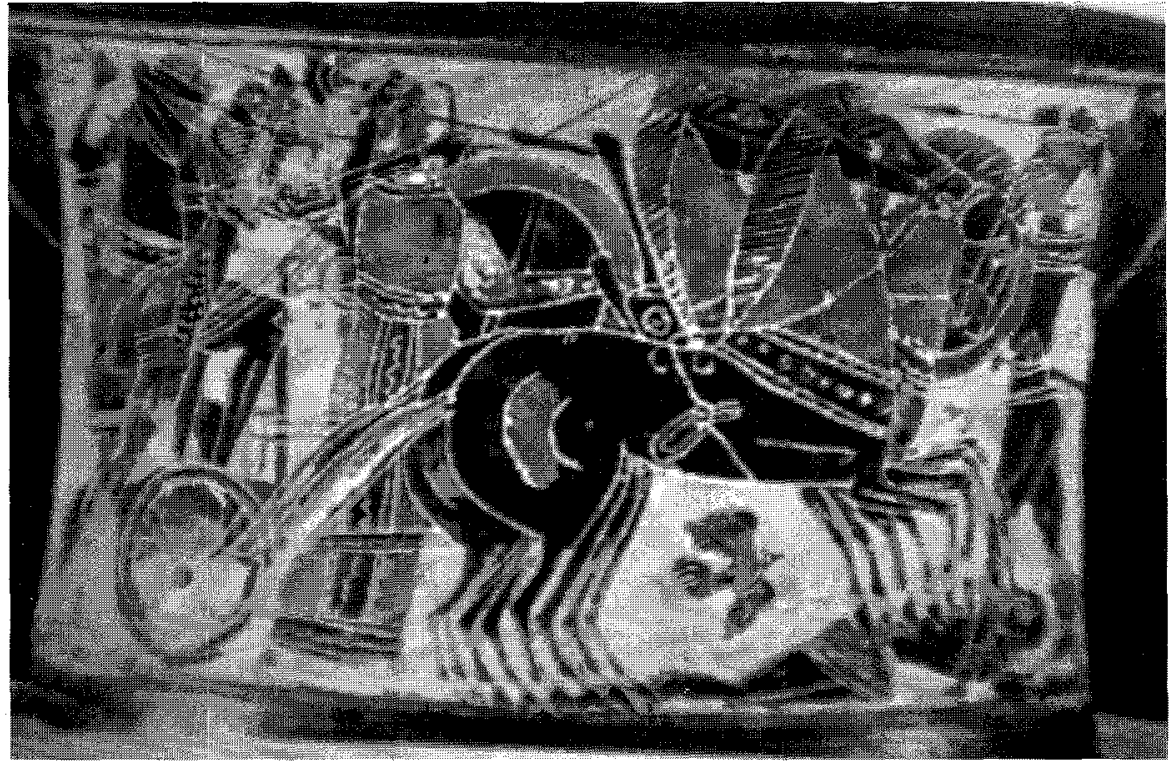

Fig. 3. Pixis. Grecia. Ca. 550 a.C. M. Berlín.

riga. Junto al carro, se observa a Atenea, de pie. Los tres lucen ya sus atributos habituales: el primero, el rayo; el segundo, el arco y las flechas, además de la piel de león, y por último, la diosa, la égida ${ }^{7}$, casco, escudo y lanza (fig. 3).

La decisiva participación bélica de los dos hijos de Zeus evidencia, además, el planteamiento griego de la supremacía de la descendencia patrilineal sobre la matrilineal. Los gigantes eran hijos esencialmente de madre y por ello no podían prevalecer sus aspiraciones frente a los vástagos más preclaros del soberano celeste. Se percibe, aquí, el substrato de la ideología patriarcal que estructuró la base del desarrollo de la polis. El apoyo que ambos brindaron a su padre, garantizaba su posición como señor del Olimpo y el predominio de los valores masculinos por él encarnados.

Otros divinos personajes fueron también representados por el arte arcaico. Algunos de ellos, como Dioniso, también estuvieron particularmen-

7 Egida-Especie de coraza, fabricada con la piel de la cabra Amaltea, nodriza de Zeus, que Atenea compartía con él. Sobre ella solía llevar la cabeza de Gorgona, regalada por Perseo, que petrificaba a quien la miraba y que jugó un papel decisivo en la ofensiva contra los gigantes (Apol. Bibl. II, 4, 1 ss.). 
te vinculados con el fin civilizador de la polis. Dioniso, hijo de Zeus y Semele, se incorporó muy pronto a la progresión histórica de la historia de la ciudad. En la época del arcontado, (683-560 a.C.), el dios tenía a su disposición a un arconte basileus para el desempeño de sus servicios religiosos. Con la llegada de la tiranía (560 a.C.), Pisístrato no sólo fomentó su culto, sino que estableció en su honor las Grandes Dionisiacas, (534 a.C.), fiestas celebradas al despuntar la primavera en la ladera sur de la Acrópolis de Atenas. En el marco de estas festividades, se forjaron las primeras representaciones teatrales, cuyo carácter panhelénico se fue gestando poco a poco. En el s. v a.C., en especial, eran foro de debate de tradiciones, valores e ideología política. De este modo, el teatro dionisiaco llegó a ser un instrumento de democratización y de afirmación de la identidad griega, siempre regido desde Atenas, la escuela de Grecia en palabras de Pericles, (Tucid. Guerra Peop. II. 41. 1-2). Dioniso fue, además, un dios educador, inventor de una de las mayores riquezas de la Grecia antigua: la vinicultura, cuyo conocimiento adquirió a través de la observación de una mítica serpiente, (Nono. Dion. XII, 293-362). Es verdad que el desenfreno orgiástico, practicado por sus adeptas o menades, parece que era provocado por una elevada intoxicación etílica; sin embargo el campo de acción, donde daban rienda suelta a sus locuras, estuvo siempre en las afueras de la ciudad. Era en parajes agrestes, donde se abandonaban al exceso y a la violencia, ya que en el ámbito cívico no se admitían tales desmanes. Sólo volvían a él cuando recobraban la calma, (Eur. Bac. 725 ss.). Esta catarsis, que Dioniso provocaba en sus fieles, no era otra cosa que una forma de purificación de las pasiones que acechaban a la polis. Su presencia como combatiente en la Gigantomaquia estaba plenamente justificada.

Los ceramistas arcaicos le representan con rostro barbado y cabeza coronada de hiedra u hojas de vid. Se atavía con vestido corto sobre el que, a veces, lleva manto o su característica nebris. Suele ir armado con coraza, lanza y escudo ático, reminiscencias del mundo homérico. A mediados del s. v a.C., el armamento desaparece, ocupando el tirso el lugar de la lanza. Hacia el 425 a.C., su figura se hace más juvenil y su semblante imberbe. Este será el modelo artístico que prevalecerá. Durante todo este largo período, el dios se suele acompañar por un cortejo de animales que muerden a los gigantes. Serpientes, perros y felinos amenazan a sus rivales como émulos de sus propias transformaciones ${ }^{8}$ (fig. 4). A partir del 475 a.C., serán sustituidos por un séquito de ménades y sátiros.

KERÉNYI, K. (1998). Dionisos. Barcelona, págs. 50 ss. OtTo, W. (1997). Dioniso. Madrid, págs. $72,74,83-85,130$. 


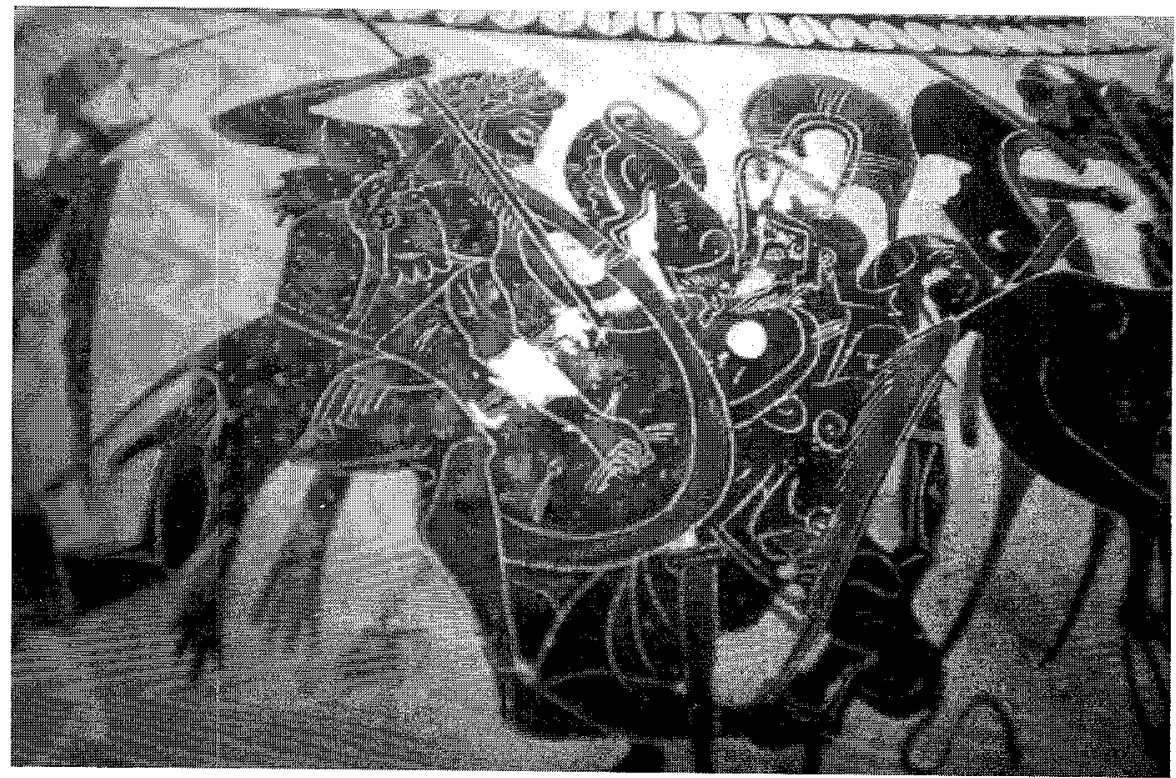

Fig. 4. Psikter. Grecia. 530-520 a.C. M. Rice (Houston, Texas).

Las gigantomaquias referidas a Posidón recuerdan, en su mayoría, el episodio de la mitología, narrado por Apolodoro, en que el dios persigue al gigante Polibotes. Este último se refugia en la isla de Cos, donde el poder divino desgaja un fragmento de ella (islote de Nisiros) y arrojándolo sobre su enemigo, logra aplastarlo, (Bibl. I, 6, 2). Esta versión se escenifica una y otra vez. Desde el 470 a.C., el tridente se convierte en su arma principal (fig. 5).

El papel privilegiado que Hera desempeñó en el panteón olímpico, le autorizó también a compartir con su esposo, la lucha por su soberanía en peligro. Pero, así como Zeus personificó los valores masculinos de aquella sociedad patriarcal, la diosa, de un modo paralelo, asumió la protección de la institución matrimonial y de la mujer casada. Era ella quien aseguraba la legitimidad de la descendencia a través del vínculo conyugal y, como consecuencia, también afianzaba la continuidad de la polis, una de cuyas bases estaba establecida sobre la legalidad de la asociación familiar ${ }^{9}$.

Los comienzos iconográficos de la diosa fueron los de una figura armada con lanza o espada y tocada con casco o birrete. Más tarde, su

9 Vidal-Naquet, P. (1974). Mito y sociedad en la Grecia antigua. Madrid, pág. 52. 


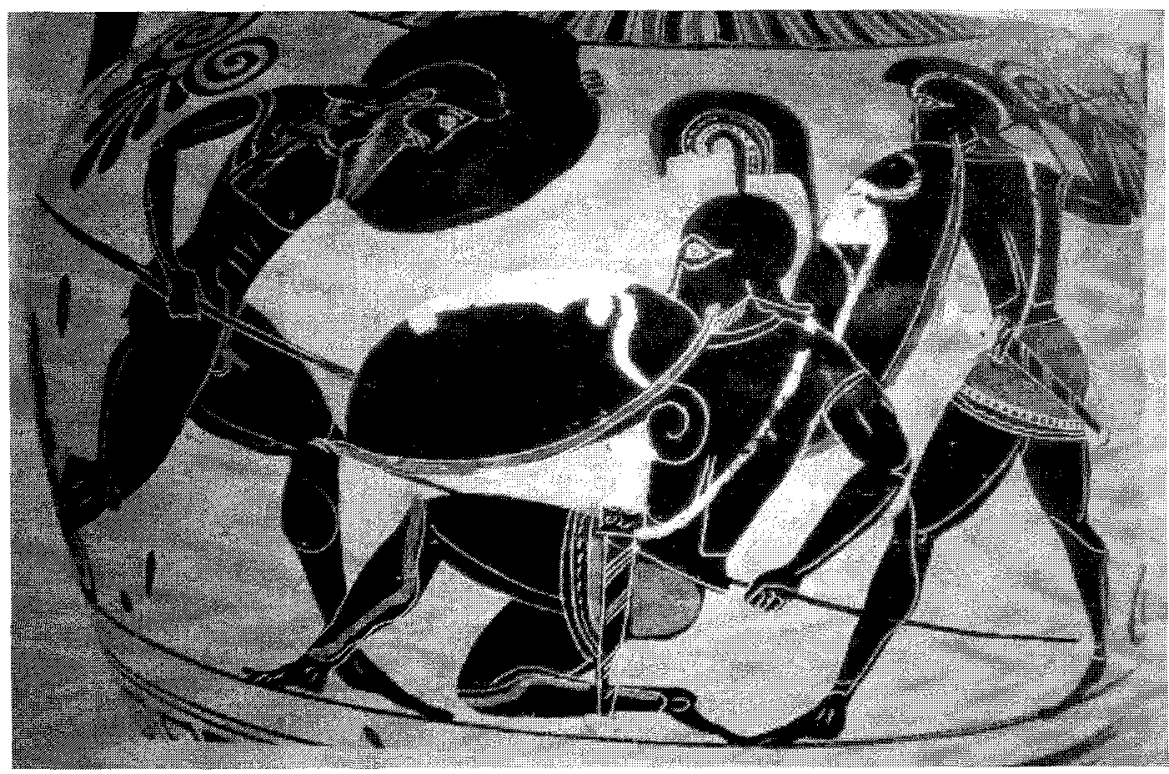

Fig. 5. Anfora. Grecia. Ca. 520 a.C. M. Wagner (Würzburgo).

imagen pierde el carácter guerrero, transformándose en una matrona cubierta de amplios velos, que ciñe sus cabellos con una diadema. Se deduce de aquí, la posición de Hera como guardiana de ese orden nuevo establecido tras la derrota de los gigantes. Aristófanes, (445-385 a.C.) en su obra Las Aves, (1731-1742; 1754) se vale del casamiento de sus protagonistas, Pisteraios y Basileia, como metáfora para la implantación de un mundo nuevo en el que la naturaleza no haya sido pervertida. Su unión es celebrada con la canción de boda de Zeus y Hera.

Este cambio en su aspecto pudo responder a la evolución de su misión femenina, expresada sobre todo al ejercer las artes de la seducción ${ }^{10}$. De aquí, que algunas representaciones se centren en el momento en que el gigante Porfirión, deslumbrado por su encanto y belleza, intenta violentarla, siendo abatido por Zeus y Heracles, (Apol. Bibl. I, 6,2).

Síntesis de las gigantomaquias del período arcaico fue, sin duda, el friso norte del Tesoro de los Sifnios, situado dentro del recinto sagrado

10 Bermejo, J., GonzÁlez, J. y Reboreda, S. (1996). Los orígenes de la mitología griega. Madrid, pág. 93. DevereuX, G. (1982). Femme et Mythe. Paris. 
del santuario de Apolo, en Delfos, (530-525 a.C.). La elección de este lugar como ámbito para la escenificación del mito, pudo estar relacionada con la labor asignada al dios oracular dentro del panteón helénico. En efecto, Apolo fue delegado por Zeus con la misión de instruir en las leyes a los helenos, (PI. Leyes II, 653b; 660E). Su propósito fue siempre anunciar a los hombres la inflexible voluntad de su padre, (Him. Hom. a Apolo, 132). Para ello iluminaba a los exegetai ${ }^{11}$ de Esparta y Atenas, y a la Pitia en el oráculo de Delfos, (Esq. Eum. 616-619). Su famoso lema conócete a ti mismo mostraba el camino, que sus fieles recorrían desde la visión adivinatoria hasta la interiorización personal. El conocimiento y la sabiduría apolíneos se manifestaban a través de la práctica de la serenidad y la armonía, valores en consonancia con el espíritu de la polis.

Sifnos fue una de las islas del Egeo que, en el s. vi a.C., trató de integrarse en el proceso cultural, político y comercial griego, dirigido por Atenas. Nada mejor que ilustrar ese deseo con la representación escultórica del combate divino en uno de los focos de erudición y ciencia religiosas del mundo helénico. Los componentes del friso, primer ejemplo artístico de relieve continuo, iban policromados sobre fondo azul, brillando al sol el bronce de sus armas. El escultor, procedente de un taller de Quíos, pero afecto a la estética ateniense, quiso identificar a cada uno de los personajes por medio de inscripciones nominales. No hay duda de la presencia de Kybéle, la gran diosa frigia, que aparece por vez primera montada en su carro de leones. En su calidad de madre de los dioses ${ }^{12}$ fue asociada muy pronto con Rea, la titánide de quien nacieron las seis grandes divinidades olímpicas, (Hes. Teog. 453 ss.). Es en esa forma como debe interpretarse su participación en la lucha contra los gigantes (fig. 6).

\section{EL CLASICISMO}

Monumento emblemático por excelencia fue el Partenón, construido entre el 447 y 432 a.C. en honor de Atenea Parthénos. El templo formó parte de las obras de reconstrucción, llevadas a cabo en la Acrópolis de Atenas, destruida por los persas durante las Guerras Médicas, (480 a.C.). La Gigantomaquia fue uno de los temas seleccionados para el programa escultórico del exterior del edificio. Ocupaba las metopas de la fachada

11 Exegetai-Intérpretes de las decisiones divinas en las liturgias de los templos y de todo to relativo a la purificación ritual que debían seguir los homicidas.

12 González Serrano, P. (1990). La Cibeles. Nuestra Señora de Madrid. Madrid, pág. 114. 


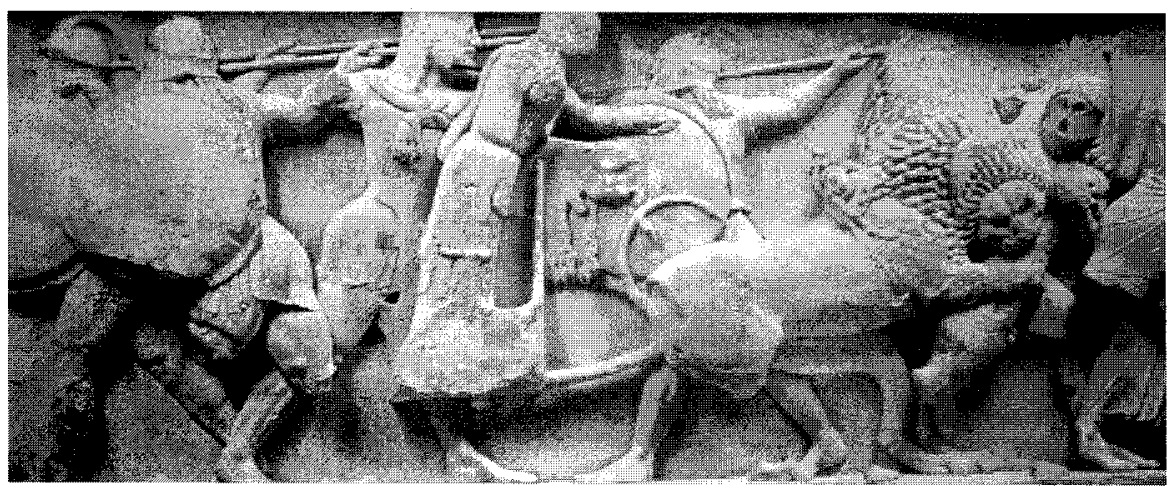

Fig. 6. Friso relivario. Tesoro de los Sifnios (Delfos, Grecia). Ca. 525 a.C. M. Delfos.

oriental, coronada, a su vez, por un frontón en cuyo tímpano se representaba el tema del Nacimiento de Atenea. Esta temática se completaba con la lliupersis y la Centauromaquia, en las metopas de las alas septentrional y meridional, respectivamente, y la Amazonomaquia, en las correspondientes a la portada occidental. Sobre ella se elevaba otro frontón en cuyo interior Atenea y Posidón se disputaban el dominio del Atica. La adopción de estos contenidos mitológicos no pudo ser por azar, ya que constituyeron un compendio de propaganda política, que difícilmente podía pasar desapercibido.

La victoria griega sobre los persas en las Guerras Médicas supuso la consolidación del sentimiento nacional en defensa de los valores ciudadanos. La superioridad numérica enemiga y los propios desajustes en la colaboración unitaria de los estados griegos propiciaron atribuir el triunfo a la ayuda de dioses y héroes, (Her. Nueve I. His. VIII, 41 y 109; Plut. Tes. 35; Plut. Tem. 15). Ello era una muestra de la aprobación divina a la democracia instaurada por Clístenes. La derrota del adversario no sería otra cosa que el castigo del Cielo contra la hybris, es decir, contra el desorden y el caos, (Esq. Persas, 115 ss.). La tiranía, que este pueblo hubiera impuesto, se identificó con injusticia y esclavitud, términos radicalmente opuestos a los de justicia y libertad pregonados por la polis, (Her. Nueve I. His. V, 56, 92 ss; VII, 103). Atenas asumió pronto el liderazgo de las ciudades de la Hélade, erigiéndose en defensora a ultranza de su utopía doctrinaria; pero sería en tiempos de Pericles cuando alcanzó su mayor esplendor. Fue en esa época cuando el Partenón se convirtió, bajo la inspiración de Fidias, en alegoría monumental del imperialismo ateniense. El arte, al servicio de la ideología del estado, exaltaba, una vez más, el predominio de la racionalidad sobre la barbarie. 
Temática similar realzaba escudo y sandalias de la gran estatua crisoelefantina de Atenea Parthénos, realizada también por Fidias, que debía permanecer en el interior del templo. El escudo reproducía en su interior una Amazonomaquia en relieve y, en su exterior, una Gigantomaquia pintada; el borde de las sandalias iba orlado con una Centauromaquia esculpida (fig. 7). La diosa, armada de pies a cabeza, ejercía su protección sobre la ciudad desde la roca sagrada. Portadora de la fuerza paterna y de la sabiduría materna, salvaguardaba la voluntad de Zeus como elemento del equilibrio de Atenas.

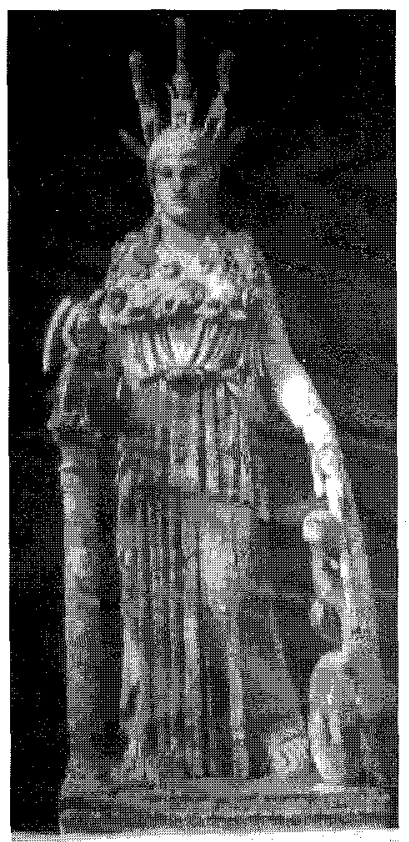

Fig. 7. Atenea Varvakeion. Copia de Atenea Parthenos (Partenón, Acrópolis Atenas), s." a.C. M. del Prado (Madrid).

Apenas quedan restos de la Gigantomaquia del Partenón. Las distintas reconstrucciones ${ }^{13}$, que se han hecho, reflejan un cambio en la concepción de los gigantes, que perduró hasta el final del arte griego: desaparecen

13 Praschniker, C. (1928). Partenonstudien. Viena Brommer, C. (1967). Die Metopen des Partenon. Berlin. VIAN, F. (1952). La guerre des géants. París, págs. 127 ss. 
las armaduras hoplíticas; luchan semidesnudos o ataviados con pieles de animales; algunos aún conservan el casco y la espada de la épica anterior; otros empuñan piedra o árboles como arma arrojadiza; la mayoría luce barba hirsuta y cabello crespo. Esta evolución figurativa contribuyó a señalar la animalidad de los rebeldes frente a divinidades ataviadas, total o parcialmente, con prendas de la indumentaria cívica griega, (Apd. Bibl. 1, 6, 2).

A partir del 430-420 a.C., la ofensiva se trasladó a las alturas. Los gigantes pretenden, entonces, asaltar la morada divina. Los ceramistas conciben este asunto por medio de dos planos, a veces separados por un arco cósmico, donde colocan a los contendientes, (figs. 8 y 9). El nuevo emplazamiento coincide con el comienzo de las Guerras del Peloponeso que terminaron con la desintegración del estado democrático. Como consecuencia, se quebraron los principios básicos sobre los que se asentaba la polis, poniéndose también en entredicho la justicia y el poder divinos ${ }^{14}$.

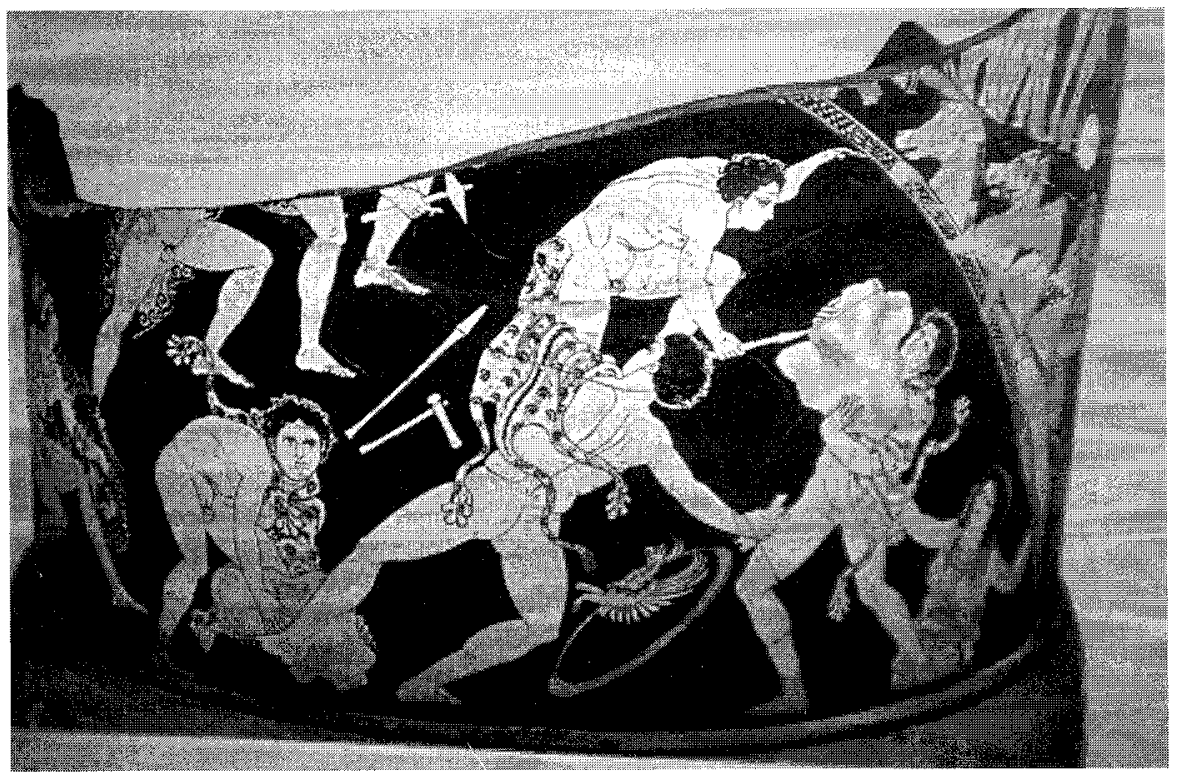

Fig. 8. Crátera. Grecia. 430-420 a.C. M. Nápoles.

14 Rodríguez Adrados, A. (1966). Ilustración y política de la Grecia Clásica. Madrid, págs. 438 ss. 


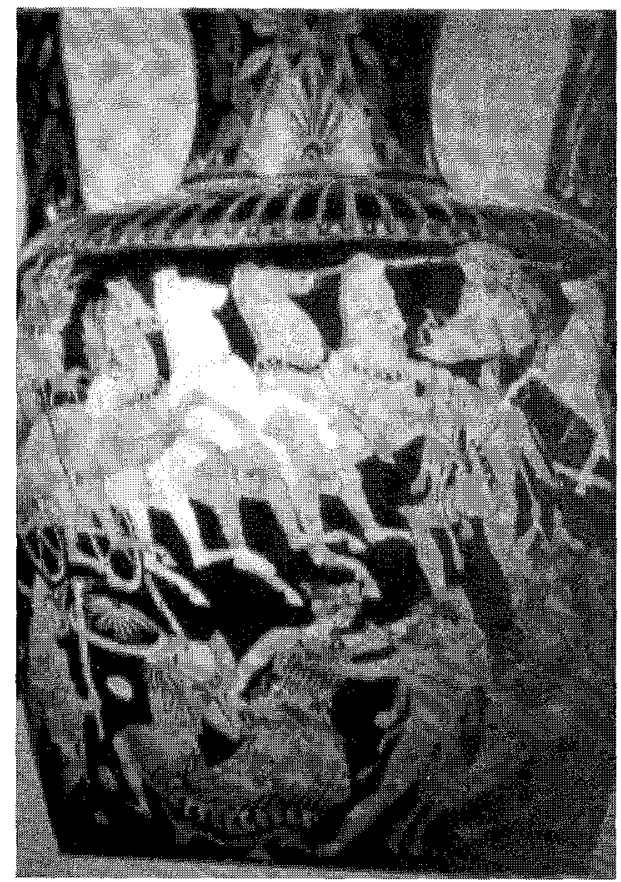

Fig. 9. Anfora. Italia Meridional. 400-390 a.C. M. Louvre (París).

No sorprende que las representaciones de la época imaginen a los causantes del caos intentando expulsar del Olimpo a los propios dioses. Aristófanes, (445-385 a.C.) se hizo eco de ello, parodiando este asunto de una forma satírica en su obra Las Aves.

A falta de un proyecto mejor, la ciudad volvió al régimen anterior, pero en lugar de evolucionar, permaneció estancada en las formas políticas del s. $v$ a.C. hasta la llegada al poder de Filipo II de Macedonia. Es por eso que la Gigantomaquia cobró de nuevo toda su vigencia y que la victoria sobre los gigantes supuso la renovación del mensaje de instauración de la polis divina. Platón abogaba, en el s. IV a.C., por el seguimiento de la regla suprema y por el retorno a la ciudad deificada. En ella, los gobernantes debían difundir los principios de dicha regla como forma de impulsar la virtud ciudadana, (Ley. IV, 709a, ss.; 712c, ss.; 715e, ss.). Pero, esta vez, los hijos de la Tierra estaban pertrechados con un arma letal. Es en esa época cuando, en el área de Italia meridional dentro de este contexto iconográfico, surge la figura del gigante de piernas serpentiformes (anguípedo). La fuerza telúrica de su madre se manifiesta en él con más fuerza que 
nunca a través de los ofidios, los simbolos maternos ${ }^{15}$. Su presencia en el sur de Italia le atestigua directamente como avatar de Tifón, monstruo de tamaño descomunal y vástago nacido también de Gea, que fue arrojado por Zeus a las entrañas del Etna (Sicilia). Allí se revolvía y se agitaba, provocando la erupción de fuego y rocas que solían arrasar la región, (Pind. Pit. I, 15 ss.). Su torso alado y sus miembros inferiores, formados por espirales de víboras, pudieron sugerir a los artífices de la época la nueva imagen del adversario divino.

\section{LA DIFUSIÓN DEL HELENISMO}

Expresión de la grandeza del Estado, de sus avatares políticos y de sus éxitos militares fue el gran altar de Pérgamo (s. II a.C.), uno de los más notables monumentos del mundo helenístico. La ornamentación del vasto friso exterior se dedicó a la representación de la gran gesta cosmogónica griega. En esta ocasión, su exégesis debía realizarse bajo el prisma ideológico y político de la monarquía atálida, continuadora de las ideas universalistas de Alejandro Magno y promotora de los modelos de la vida y las artes de la Atenas clásica. Efecto del nuevo helenismo fue el nacimiento de un tipo diferente de ciudad, más universal, multirracial y plurilingüe, donde se fundieron antiguas y nuevas tradiciones, ideas y formas de pensar. La polis precedente había dado paso a la cosmopolis. La importancia de Pérgamo (Asia Menor) como tal, se inició en el s. IV a.C., alcanzando su cenit con Atalo I (241-197 a.C.) y Eumenes II (197-159 a.C.). Fueron las victorias de ambos sobre gálatas, bitinios y pónticos las que les acreditaron como los más idóneos paladines en la defensa de la cultura griega.

Para inmortalizar su triunfo sobre los galos, Eumenes II ordenó levantar el monumental altar, estableciendo así un paralelo histórico con Pericles y la construcción del Partenón. La campaña se desarrolla a lo largo de cien losas de mármol, de 2,30 m. de altura por $1 \mathrm{~m}$. de longitud (fig. 10). Aunque la identidad de algunas figuras ha sido objeto de debate, la de otras ha sido reconocida gracias al hallazgo de inscripciones nominativas. Antaño se colocaron encima o debajo de cada escultura, siguiendo el didáctico procedimiento empleado ya en el Tesoro de los Sifnios (Delfos). Como los templos griegos, el edificio apuntaba hacia el oriente, y es en

15 VÁZQUEZ, A. (1981). La serpiente en el mundo antiguo. La serpiente en las religiones mediterráneas. Boletín de la Asociación de Amigos de la Arqueología, 14, págs. 33-39. 


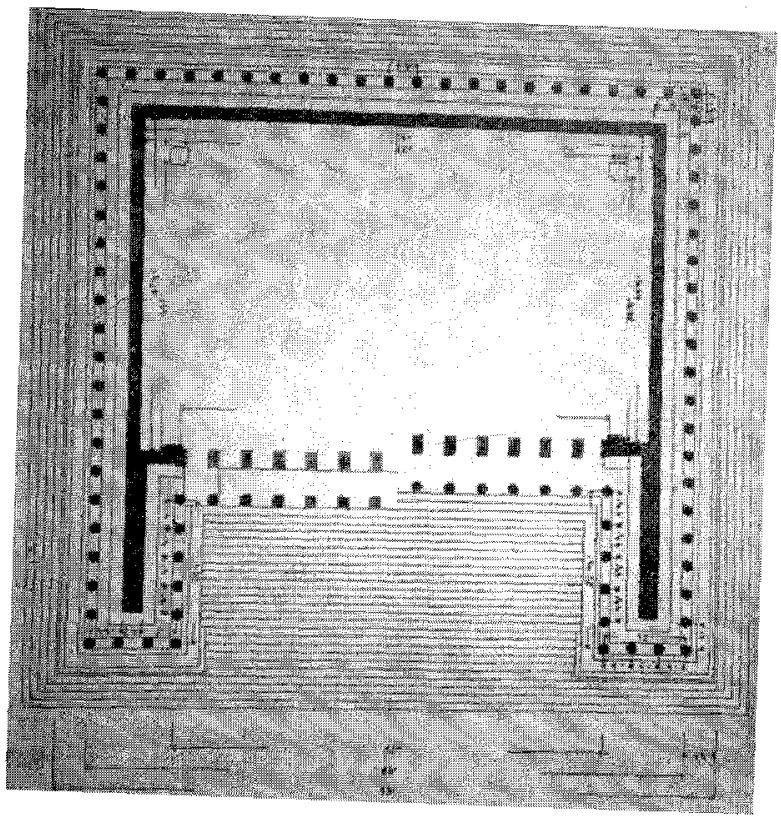

Fig. 10. Planta del altar de Pérgamo (Asia Menor). Según Kähler, s. Il a.C.

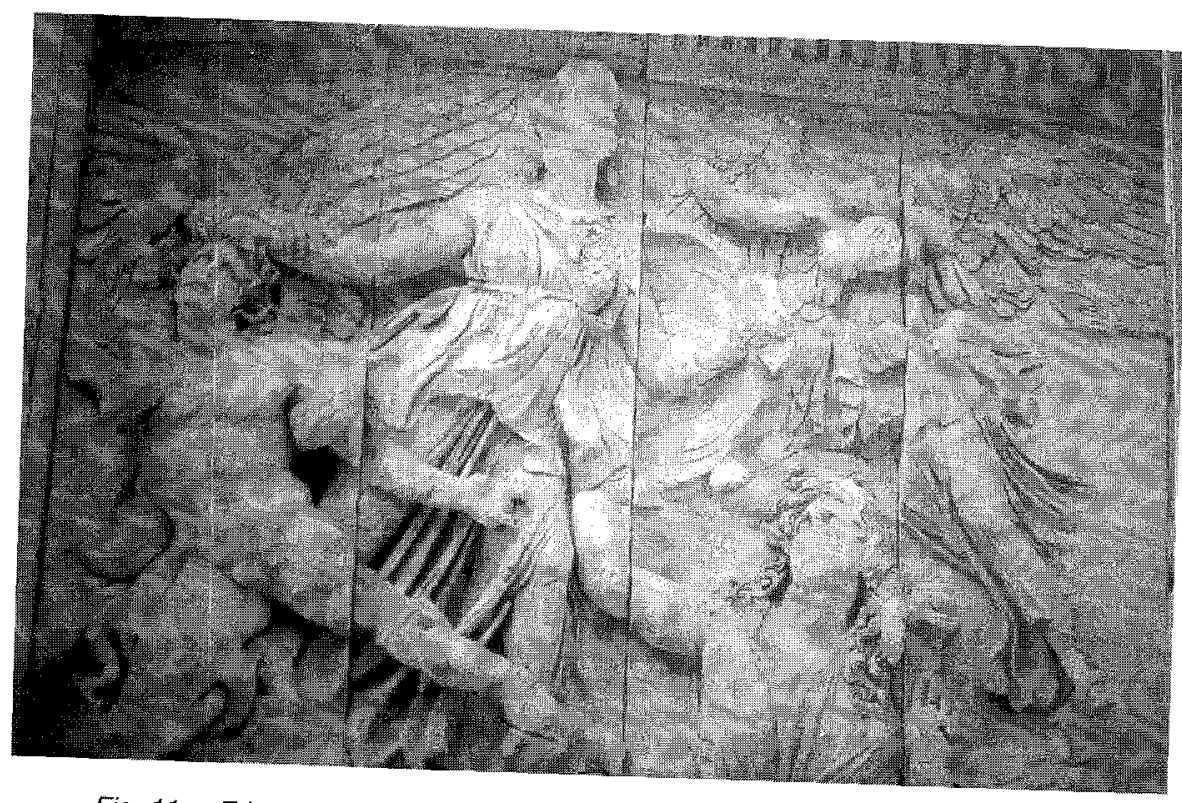

Fig. 11. Friso relivario. Altar de Zeus (Pérgamo, A. Menor), s, "la.C. M. Berlín. 
ese lado, donde se agrupan las deidades olímpicas. Entre ellas, Heracles, Zeus y Atenea forman la misma trilogía iconográfica que en otro tiempo (fig. 11). Les acompaña Hera, que guía una cuadriga de caballos alados, probablemente los 4 vientos: Boreas, Céfiro, Noto y Euro. En los laterales figuran las divinidades de la luz y las de las tinieblas, que dan una dimensión cósmica a la batalla. El conjunto se completa con los dioses marinos, presididos por Posidón, y con Dioniso y su cortejo, distribuidos entre las alas que forman los salientes y el interior de la escalera central (fig. 12). Entre ellos se mezclan y entrelazan los gigantes, según el esquema habitual. Muchos ostentan rasgos animalísticos, como garras de león, cuernos de toro ${ }^{16}$ o escamosas piernas serpentiformes, siguiendo el modelo itálico ya citado (fig. 13). Sin duda, el repertorio figurativo y estilístico del Partenón influyó de manera poderosa en las concepciones pergamenas, pero el dinamismo de la acción, la torsión de las poses corporales y las tensas y musculosas anatomías poco tienen ya que ver con la tradición clásica. Por otro lado, la dolorosa agonía, reflejada en el semblante de los vencidos,

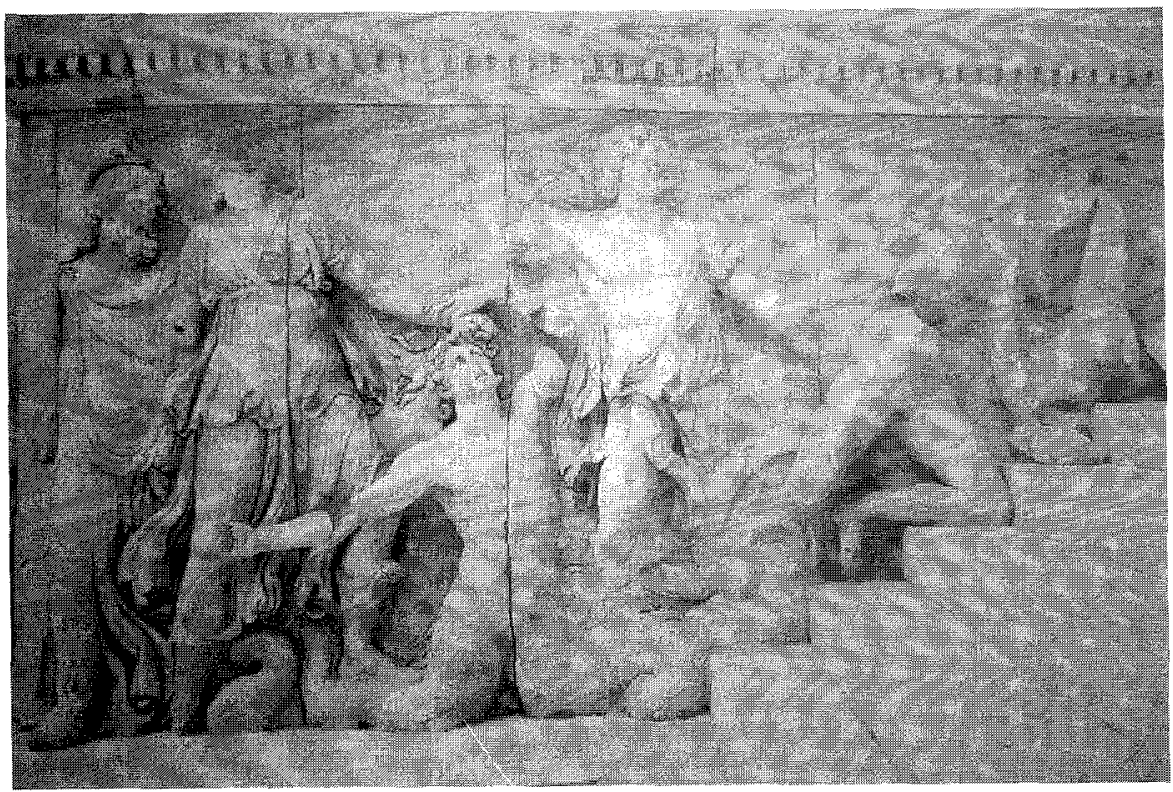

Fig. 12. Friso relivario. Altar de Zeus (Pérgamo, A. Menor), s. II a.C. M. Berlín.

16 DELGado, C. (1996). El toro en el Mediterráneo. Análisis de su presencia y significado en las grandes culturas del mundo antiguo. Madrid, págs. 149 ss. 


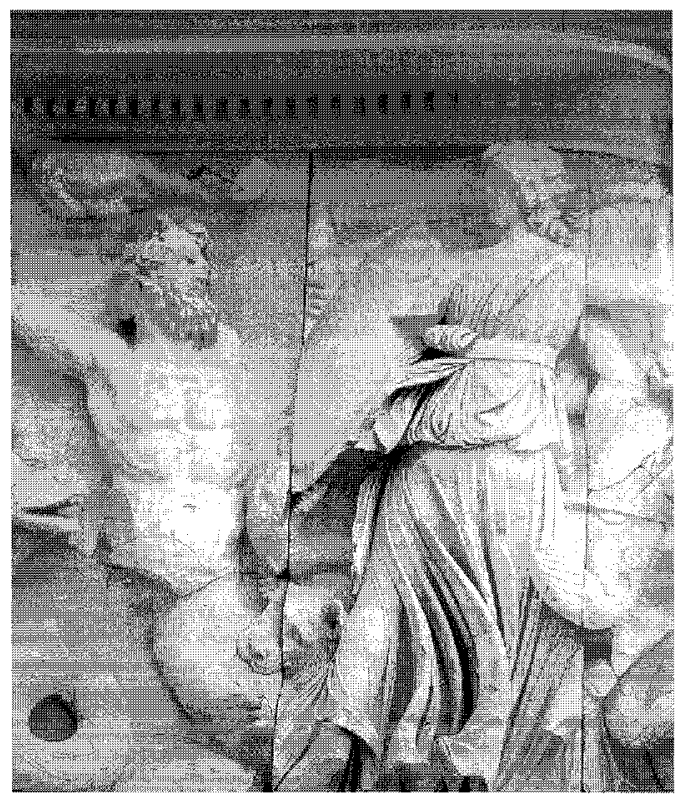

Fig. 13. Friso relivario. Aitar de Zeus (Pérgamo, A. Menor), s. "l a.C. M. Berlín.

contrasta de un modo elocuente con la serenidad que emana de las divinas fisonomías (fig. 14). Los escultores plasmaron en aquellos la imagen del gálata inculto y feroz, de cabello largo y encrespado, mentón a menudo barbado y entrecejo fruncido y atormentado. El Himno IV a Delos, de Calímaco de Cirene, (310-240 a.C.), es el primer testimonio escrito de ese nexo de unión entre gigantes y gálatas.

Es muy probable que en la lectura del friso no fuesen ajenas ciertas corrientes filosóficas y literarias que se propagaron por las ciudades de la oikumené helenística. La decadencia de la polis, generada tras las Guerras del Peloponeso, sumió al ciudadano griego en una pérdida de identidad ante su incierto futuro y en una tibieza cívica y religiosa. Estoicos, epicúreos y cínicos cooperaron, de un modo decisivo, en la formación de las nuevas corrientes filosóficas que perduraron más allá del helenismo. Contemporáneo de Alejandro Magno, Diógenes Laercio se había ya proclamado a sí mismo cosmopolita, (Vid. filos, VI, 22). Fue Zenón de Citio, semita oriundo de la isla de Chipre y fundador del estoicismo, quien se esforzó por mostrar la similitud entre la ciudad y el cosmos, (Stoic. frag. I, 171 ss; II, 441 ss.). Proponía un mundo sin estados, como una sola ciudad regida por una única ley divina y universal. El sabio 


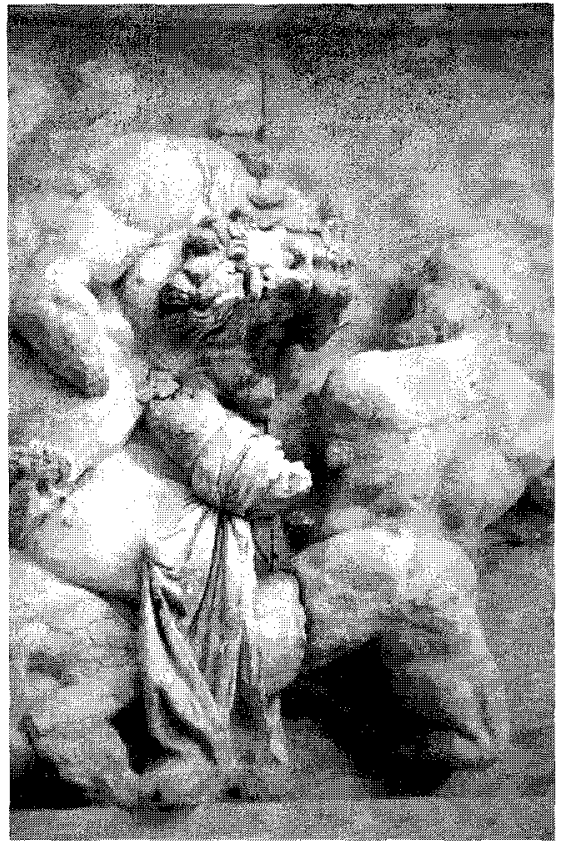

Fig. 14. Friso relivario. Altar de Zeus (Pérgamo, A. Menor), s. II a.C. M. Berlín.

seria aquel capaz de descubrir su íntima conexión con el logos o razón última que anima el universo. La armonía con ese logos debía lograrse a través de la inteligencia, chispa divina que todo hombre posee. La virtud, por tanto, se fundaba en la razón perfecta llegada a su más alto grado de conocimiento, liberando a quien la practicaba del movimiento desordenado de las pasiones (deseo, placer, miedo, dolor) y dotándole del don de la impasibilidad. La Gigantomaquia de Pérgamo se transforma en la expresión de un drama simbólico, donde Zeus encarna a ese sumo intelecto, cimiento de toda justicia y dador de todos los dones, a quien Cleantes de Assos dedicó el hermoso himno que pudo inspirar el modelo pergameno, (Stob. Eglog. I, 1, 12). La masiva intervención de la familia divina sugiere ese triunfo arrollador, que traería consigo la llegada de la cosmopolis entre los hombres. Un anticipo de ella brota del sosiego que reflejan sus rostros, en contraste con las emociones encontradas que desprenden los de sus adversarios. Es la primacía de la virtud y su dominio sobre la debilidad de las pasiones.

Analizando el friso con atención, se observa la significativa agrupación de las divinidades por vínculos de consanguinidad y la superioridad nu- 
mérica de las deidades femeninas sobre las masculinas ${ }^{17}$, en particular la de aquellas a quienes la mitología atribuye el papel de madre. Así, Gea emerge de la tierra rodeada por sus descendientes, los gigantes; la titánide Leto figura junto a sus hijos Apolo y Artemis; otra titánide, Tea, se rodea de sus vástagos Helios (el sol), Selene (la luna) y Eos (la aurora); la nereida Anfitrite se sitúa cerca de Tritón, etc. Estos factores no parecen casuales. La solidaridad entre parientes y la fertilidad de las mujeres fueron valores cuyas raíces se remontan a la sociedad hesiódica y en los que siempre se fundó la estabilidad de la polis. Las propias tesis estoicas basaban la prosperidad de un estado en el equilibrio familiar. El gran friso pergameno era un alegato del tradicional espíritu heleno, a la vez que un testimonio del caos generado por la discordia parental. Se justifica, así, la posición central de Hera, consorte de Zeus y prototipo de esposa griega. Ella protegía, además, a las mujeres encintas, garantizando, en consecuencia, la supervivencia de un estado que en el s. I a.C. atravesaba una grave crisis de natalidad. Su importancia aumentó hasta llegar a constituirse en patrona y benefactora de la estirpe de los atálidas.

\section{CONCLUSIÓN}

El tema de la Gigantomaquia constituye para el mundo griego uno de los signos más importantes de su representatibidad. No fue sólo un episodio más de su compleja mitología, sino una forma de entender la vida, el pensamiento o la religiosidad. Su evolución a través de los distintos contextos en los que se utilizó, fue una forma de lenguaje para expresar el ideal panhelénico, que impulsó a Alejandro al cumplimiento de su sueño universal.

17 FEHR, B. (1997). Society, Consanguinity and the Fertility of Women. En, P. Bilde, Conventional Values of the Hellenistic Greeks. Aahrus. 